IRSH 60 (2015), pp. 349-378 doi:10.1017/S002085901 5000504

(C) 2015 Internationaal Instituut voor Sociale Geschiedenis

\title{
Waiters, Waitresses, and their Tips in Western Europe before World War I*
}

\author{
PATRICIA VAN DEN EECKHOUT \\ Department of Political Sciences, Vrije Universiteit Brussel \\ Pleinlaan 5, I050 Brussels, Belgium
}

E-mail: pvdeeckh@vub.ac.be

\begin{abstract}
AвSTRACT: In nineteenth-century restaurants and cafés, customers' tips provided the income of an increasing number of waiters and waitresses. Not only did employers refrain from paying serving staff a fixed wage, the latter had to share their employers' general expenses, while some even had to pay a fee for the privilege of working. Exploring newspapers, pamphlets, reports, and union sources, the article discusses in a comparative way how and why these practices were deployed in Amsterdam, Brussels, Vienna, London, and French and German cities. As a result of the overcrowding of the labour market in hospitality, hiring workers became not only a cost-free transaction, it even developed into a source of income. Serving staff paid for the opportunity to collect tips, even if their increasing number reduced individual income. However, as a result of the tipping system, such staff often managed to secure higher "wages" than they would normally have earned.
\end{abstract}

On Is and 20 May I9I3 respectively, twelve and twenty-three garçons d'botel from Paris filed a complaint with the Ghent Conseil de Prud'hommes, the local labour tribunal. They had been contracted to come to work during the Exposition universelle et internationale, the World's Fair, but on their arrival their employer had had nothing to offer. These men, sometimes accompanied by their wives, had travelled from Paris to Ghent with the prospect of living on le profit et la nourriture (profit and meals). ${ }^{\mathrm{I}}$ Le profit consisted of the tips (called pourboire, étrennes, or gratifications in French, Trinkgeld in German, drinkgeld or fooi in Dutch) they would collect. In 1798 , the Dictionnaire de l'Académie française defined a pourboire as "petite libéralité en signe de satisfaction", a small act of generosity as a mark of satisfaction. ${ }^{2}$

* I would like to thank Frank Winter for the final revision of the text.

I. Patricia Van den Eeckhout, "Allen daarheen! Koks en kelners op de Wereldtentoonstelling van I9I 3 in Gent”, Brood E Rozen, I (2013), pp. 29-5 I.

2. Dictionnaire de l'Académie française (Paris, I798), II, p. 337. 
It is remarkable that these small acts of generosity were called "profit" and that the waiters involved were not paid a wage. Twenty-eight Brussels garçons de café who also filed a complaint even had to pay frais d'entrée (admission fees) to be allowed to work in the Restaurant des Floralies - Gambrinus Exposition. This raises questions regarding the character of the relationship between such serving staff and the publican or restaurateur in whose premises they were employed. Does this constitute a wage relationship, since no wage was involved? And why, where, and when was this mode of remuneration introduced into the hospitality sector, and how was it perceived by the parties involved?

Waiters were not the only occupational category whose income consisted largely or entirely of tips: at the beginning of the twentieth century, hairdressers, coachmen, concierges, postmen, couriers, porters, and removers were similarly employed, while lavatory attendants and ushers in theatres and cinemas had to pay a fee to be allowed to work. ${ }^{3}$ The services provided by these workers were often intangible and could not "be produced in advance of the service encounter", while "the customer frequently participated in the production of the service". ${ }^{4}$ The result was a "workeremployer-customer triangle" instead of a "bilateral employment relationship". In the discussion of the historical development of various forms of remuneration of work (money wages, payments in kind, board and lodging, perquisites, fringe benefits, gratuities), ${ }^{6}$ the involvement of third parties has received little attention. The need to pay a fee in order to get a job appears, however, in the discussion of the role of foremen, subcontractors, and middlemen in the recruitment of workers. ${ }^{7}$ The hospitality sector had its specific intermediaries: the bureaux de placement or private employment agencies which serving staff and kitchen personnel used to find a job. ${ }^{8}$

3. Jean-Louis Bach, Le pourboire-salaire (Paris, I910), pp. 17-33, 53-82. On the leasing of toilet facilities, see Das Berliner Caféhausgewerbe. Die wirtschaftliche Lage der Angestellten (Berlin, I9I I), pp. 52-54.

4. Holly J. McCammon and Larry J. Griffin, "Workers and their Customers and Clients: An Editorial Introduction", Work and Occupations, 27 (2000), pp. 278-293, 279-280.

5. Einat Albin, "A Worker-Employer-Customer Triangle: The Case of Tips", Industrial Law Journal, 40 (201 I), pp. I8 I-206.

6. Jason Ditton, "Perks, Pilferage, and the Fiddle: The Historical Structure of Invisible Wages", Theory and Society, 4 (1977), pp. 39-71; Reinhold Reith, Lohn und Leistung. Lohnformen im Gewerbe 1450-1900 (Stuttgart, 1999); Leonard Schwarz, "The Formation of the Wage: Some Problems", in Peter Scholliers (ed.), Real Wages in I 9 th and 2oth Century Europe: Historical and Comparative Perspectives (Oxford, I 989), pp. 2 I-39; Peter Scholliers and Leonard Schwarz (eds), Experiencing Wages: Social and Cultural Aspects of Wage Forms in Europa Since I500 (London, 2003).

7. See, for example, Gunther Peck, Reinventing Free Labor: Padrones and Immigrant Workers in the North American West, I880-1930 (Cambridge, 2000); Patricia Van den Eeckhout (ed.), Supervision and Authority in Industry: Western European Experiences, I 830-1939 (Oxford, 2009). 8. On the character of these employment agencies, see the following source from the International Labour Office striving for their abolition: Bureau International du Travail. Conférence 
The fees that these bureaux de placement demanded for their mediation have to be distinguished, however, from the daily fee serving staff had to pay to the publican or restaurateur to be allowed to work in an establishment. In fact, the daily "stage fee" that twenty-first-century erotic dancers have to pay club owners bears the most resemblance to serving staff's pre-war "entrance fee".?

In order to answer the questions raised by the working conditions of serving staff, I screened a wide range of sources relating to the period before World War I, including digital collections of French, Belgian, Dutch, British, and Austrian newspapers, for references to tipping in the context of restaurants and cafés. ${ }^{10}$ While I do not exclude hotel workers, I focus on waiters and waitresses in cafés and restaurants since my screening of the sources revealed that some of the hotel staff were in contact with customers less frequently, more often received a fixed wage, and appeared to be less dependent on tips. My investigation ends with World War I because in the interwar period the emerging collectivization of labour relations in the countries considered also influenced (albeit delayed and in varying degrees) modes of remuneration in the hospitality sector. Dealing with these subsequent developments merits proper analysis in a separate article.

\section{TIPPING IN CAFÉS AND RESTAURANTS: REMNANTS OF DOMESTIC SERVICE?}

According to Kerry Segrave these small acts of generosity had their origins in domestic service. Since the Tudor period "visitors to private homes were

internationale du Travail, seizième session 1932, Suppression des bureaux de placements payants (Geneva, I932).

9. Holly J. Wilmet, "Naked Feminism: The Unionization of the Adult Entertainment Industry", Journal of Gender, Social Policy E the Law, 7 (1998/99), pp. 465-498; Suzanne Bouclin, "Exploited Employees or Exploited Entrepreneurial Agents? A Look at Erotic Dancers", Canadian Woman Studies, 23 (2004), pp. I 32-I 37.

I0. I screened French and Dutch newspapers on gallica.bnf.fr and www.delpher.nl respectively. The digitized collection of Austrian newspapers has been made available by the Austrian National Library through ANNO. Historische Zeitungen und Zeitschriften. It is, however, limited to the years 1700-1875 and 1914-1918. The digitized collection of pre-war Belgian newspapers was not available online until recently and was searched in the Royal Library in Brussels. Digitized British newspapers were screened through commercial providers (The British Newspaper Archive and UKPressOnline), as far as they were accessible to non-institutional customers. I also explored Dutch and international pamphlets and reports related to the hospitality sector kept in the library of the International Institute of Social History in Amsterdam, while in Paris I consulted the archives of the Féderation des travailleurs de l'alimentation, one of the sections of the Confédération générale du travail. Several books and pamphlets were retrieved through www.hathitrust.org. While I managed to collect quite a few reports and pamphlets on the hospitality sector in Germany, I was unable to find German historical OCR-searchable newspaper collections online. 
expected to give sums of money (known as "vails") at the end of a visit for

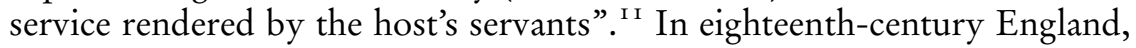
employers' tips and guests' gratuities increased domestic servants' wages. ${ }^{{ }^{2} 2}$ In affluent households, which entertained a lot, tips not only supplemented wages, they actually even exceeded them, making guests and not the employer the most important source of servants' income. Finding out whether a position offered the prospect of large tips was therefore an important consideration in servants' choice of a master, both in London and the countryside. ${ }^{13}$ However, male servants were more often in a position that generated generous tips than their female counterparts. ${ }^{14}$ In the second half of the eighteenth century a crusade against vails subsequently led to their demise. ${ }^{\text {I5 }}$ But although the Caledonian Mercury expressed its satisfaction in 1839 that the practice of giving vails to servants had been abolished, ${ }^{16}$ the custom never entirely disappeared. ${ }^{17}$

"Vails was an established practice", and not long after becoming so, Segrave observes, tipping spread to restaurants and hotels. ${ }^{18}$ It remains to be seen whether this was as self-evident as is claimed, and one wonders whether similar developments occurred on the continent, since vails were regarded as "unique to Britain". ${ }^{19}$ Although in France, too, étrennes et gratifications supplemented servants' wages, ${ }^{20}$ it remains unclear whether these practices formed the basis of tipping in restaurants and cafés. Moreover, while the practice of giving tips to domestic servants could explain why waiters and waitresses also expected this "little extra", it does not explain why the Parisian waiters coming to work in Ghent in I9I 3 expected no wage at all and were prepared to work for tips only, while their Brussels colleagues were willing to pay a fee in order to be allowed to serve.

I I. Kerry Segrave, Tipping: An American Social History of Gratuities (Jefferson, NC, I998), p. I. I 2. Jacob F. Field, "Domestic Service, Gender, and Wages in Rural England, c.1700-I860", Economic History Review, 66 (2013), pp. 249-272, $255^{-2} 56$.

I3. D. Marshall, "The Domestic Servants of the Eighteenth Century", Economica, 25 (I929), pp. I 5-40, $24-25$.

I4. Tim Meldrum, Domestic Service and Gender, 1660-1750: Life and Work in the London Household (Harlow, 2000), p. 204.

I s. Marshall, "The Domestic Servants of the Eighteenth Century", pp. 34-38; "Abolition of Vails to Servants", Morning Post, 7 February i 855.

I6. "Perquisites of Servants", Caledonian Mercury, 23 December I 839.

17. "On Servants' Vails", Leeds Intelligencer, 20 February I 823; "Vails to Servants", Glasgow Daily Herald, I 2 March I 868; Roger C. Richardson, Household Servants in Early Modern England (Manchester, 2010), p. 89.

I8. Segrave, Tipping, p. 4 .

19. Jerry White, London in the Eighteenth Century: A Great and Monstrous Thing (London, 20I2), p. 233.

20. Claude Petitfrère, L'oeil du maître: maîtres et serviteurs de l'époque classique au romantisme (Paris, 2006), pp. 96-98. 
There were undoubtedly many similarities between the work done by waiters and waitresses and that done by domestic servants in the private sphere of the home. ${ }^{21}$ As opposed to the latter, however, waiters and waitresses were employed in the context of a business enterprise: they did not serve their employer as a private person, but in the employer's capacity of entrepreneur in the service sector. But often the distinction between a butler and a waiter, between a maid and a waitress was far from clear. The proliferation of hotels, restaurants, and cafés in the course of the nineteenth century undoubtedly contributed to the emergence of serving staff as a distinctive occupational group, but for the moment this history is still largely in the process of being written. However, this paper will not focus on the latter, nor on the possible transfer of tipping from domestic service to the hospitality sector; instead it will try to find out how widespread was the practice of working for tips only and paying a fee to be allowed to work in restaurants and cafés, and what such practices tell us about the labour relationship between serving staff and their employers. First of all, though, the gender aspect of labour in the hospitality sector has to be addressed.

\section{WAITING AND GENDER}

Going through newspapers and union sources with regard to waiting at table in the long nineteenth century, one can easily forget that some of the serving staff in cafés and restaurants were women. Most of the information with respect to tipping refers to men, although several pamphlets denouncing its demoralizing effects devote a paragraph to the fact that in some cases the line between waitresses and women involved in prostitution was very thin. ${ }^{22}$ A pamphlet discussing the condition of waitresses in Berlin in the I 890 s even managed to devote its entire study to Animierkneipen, where barmaids were expected to drink with the customers. ${ }^{23}$ Since gender might be an important variable with regard to modes of remuneration, information on the position of women (not related to their employer) in the catering sector is needed.

However, with the exception of Germany, concrete and precise information with regard to the numbers of women waiting at table in western Europe is lacking. Based on what is known of gender ratios in the German hospitality sector, one might conclude that the gender distribution among serving staff varied according to region, level of urbanization, city size, and

21. On the history of domestic workers, see the recent volume: Dirk Hoerder, Elise van Nederveen Meerkerk, and Silke Neunsinger (eds), Towards a Global History of Domestic and Caregiving Workers (Leiden [etc.], 2015).

22. Winfried Speitkamp, Der Rest ist für Sie! Kleine Geschichte des Trinkgeldes (Stuttgart, 2008), pp. $76-84$.

23. Karl Schneidt, Das Kellnerinnen-Elend in Berlin (Berlin, I893). 
type of establishment. Leaving out head waiters and apprentices, the data from an investigation conducted in 1893 reveals that 48.3 per cent of serving staff were female, but there were notable regional differences: while the proportion of women was 17.5 per cent, 39.3 per cent, and 44.4 per cent in north-west, north-east, and central Germany respectively, it was 77.2 per cent in the south of the country. In general, the proportion of waiters increased with the size of the establishment (and probably its prestige), while hotels had a higher share of men than restaurants did. Large cities had fewer female servers ( 34.8 per cent) than middle-sized ( 50.7 per cent) and small cities (68.3 per cent) did, but here, too, regional differences have to be taken into account: in Berlin only 25.6 per cent of the serving staff were women, but in Munich the corresponding figure was 85.8 per cent. ${ }^{24}$ In the south of Germany waitresses had a much better image than in the north, where they were more often associated with prostitution. ${ }^{25}$ However, engaging Bavarian waitresses for marksmen fairs in the summer and Bockbierfeste in the winter became increasingly popular in other parts of Germany too. ${ }^{26}$

The information with regard to female serving staff in other countries is far more disparate, but in general one can conclude that hotels and middleclass and elite restaurants and cafés were the preserve of waiters. In the French sources I screened, waitresses are seldom mentioned as employees of regular restaurants and cafés, but rather as les bonnes in the Parisian chain restaurant Bouillon Duval, "specialized in serving meals of boiled and roasted meats in modest and clean surroundings". ${ }^{27}$ However, at the beginning of the twentieth century, waiters' unions complained about the increasing employment of women in cafés-restaurants and brasseries, which allegedly led to male unemployment and a deterioration of morals. While some pleaded for the prohibition of women's work in these venues, others underscored the necessity of the unionization of female employees. ${ }^{28}$

24. Kommission für Arbeiterstatistik/Deutschland, Erhebung über die Arbeits- und GehaltsVerbältnisse der Kellner und Kellnerinnen (Berlin, 1894), p. 92. The survey covered 4,378 waiters, 4,093 waitresses, and 803 headwaiters.

25. Heinrich Peter, Zur Lage der Kellnerinnen im Grossherzogtum Baden (Heidelberg, 1907), pp. I, 5-7. On the (self-) image of waitresses in Germany, see Brigitte Kerchner, "Die 'unsittliche Kollegin'. Anerkennung und Missachtung als gewerkschaftliche Strategien im Gastwirtsgewerbe (1891-1928)", Internationale wissenschaftliche Korrespondenz zur Geschichte der deutschen Arbeiterbewegung, 34 (1998), pp. 465-496.

26. Hugo Poetzsch, Geschichte des Zentralverbandes der Hotel-, Restaurant-, und Caféangestellten (Berlin, I928), pp. 298-301.

27. Barbara Wheaton, "Expositions universelles", in Oxford Symposium on Food and Cookery 1991. Public Eating: Proceedings (London, 1991), pp. 301-305, 304.

28. Confédération générale du travail. Fédération nationale des travailleurs de l'alimentation, $2 m e$ congrès national tenu à Lyon les 25,26 et 27 septembre 1903 (Paris, 1904), p. I7; idem, 3 me congrès national des corporations ouvrières de l'alimentation tenu à Bourges les 6, 7, 8, 9, Io septembre 1904 (Paris, 1904), pp. 88-89. 
Viennese waiters were also hostile to Mädchenbedienung, but, despite their efforts to curtail the latter, by I9I 352.8 per cent of serving staff in restaurants and $4 \mathrm{I}$ per cent of those in cafés were women. ${ }^{29}$

With regard to London, Charles Booth stated in I896 that "the large and rapidly increasing class of waitresses is principally to be found" in tea and other refreshment rooms. ${ }^{30}$ Their incomes were meagre, but their careers were expected to be short since the teashop was regarded "as a half way house between school and the altar". ${ }^{3}$ For the chain of Lyons teashops established in London in 1894, waitresses were hired, but the upmarket restaurants the company opened a few years later had waiters..$^{32}$ Although the word "barmaid" suggests employment in a particular place, it appeared to be difficult to distinguish barmaids from waitresses since both worked in pubs, restaurants, and hotels. ${ }^{33}$ Waiters and their unions regularly questioned the employment of women in front-of-house functions in hospitality by associating this with prostitution. When the Glasgow licensing magistrates tried to ban barmaids in 1902, Paul Vogel (a former German waiter and secretary of the Amalgamated Waiters' Society) applauded the decision and suggested that London would follow suit. ${ }^{34}$ As a result of a labour shortage in England during World War I, there was an increasing demand for waitresses. While the latter had until then worked in tearooms and dairies, according to the Daily Express, they now had the opportunity to extend their activities to hotels and smart restaurants. ${ }^{35}$

A brochure on the condition of waiters published in 1904 argues that in the Netherlands waitresses were a rarity, except in big cities, where they were somewhat less exceptional. ${ }^{36}$ However, an enquiry with regard to the hospitality sector published by the city of Amsterdam in 1907 found only about twenty women earning a living as waitresses: they were almost all German, or at least German-speaking. ${ }^{37}$ The insistence in both cases that

29. Hugo Poetzsch, Geschichte der Zentralorganisation der Hotel-, Gast- und Kaffeehausangestellten und verwandter Berufe Österreichs (Vienna, I93 I), pp. I 44-I 47, 294.

30. Charles Booth, Life and Labour of the People in London (London, I903; published as vol. VIII in the edition of 1896 ), p. 237.

31. Barbara Drake, “The Tea-shop Girl”, Women's Industrial Nerws, I7:6I (1913), pp. I I 5-I 29; "Teashop Girls", The Courier, 4 June I 914.

32. Peter Bird, The First Food Empire: A History of J. Lyons \& Co (Chichester, 2000), p. I I 4.

33. Eliza Orme, "Conditions of Work of Barmaids, Waitresses, and Book-Keepers Employed in Hotels, Restaurants, Public-Houses, and Other Places of Refreshment”, in Royal Commission of Labour, The Employment of Women (London, I893), pp. 197-229.

34. "Banishing the Barmaid", Nottingham Evening Post, 7 April 1902; "The Abolition of the Barmaid”, Evening Telegraph, 28 January 1903.

35. "Growing Demand for Well-Trained Waitresses", Daily Express, 23 June I9I 5; "Waitresses Needed in Good-Class Hotels”, Daily Express, го May 1916.

36. Jacob C. Eringaard, Kellners. Vakorganisatie en vakbeweging der café-, restaurant-, hotel- en societeitsgeëmployeerden (Delft, 1904), p. 26.

37. De toestand der bedienden in het hotel- en cafébedrijf te Amsterdam (Amsterdam, 1907), I, pp. $42-43$. 
the study dealt only with waitresses earning a living by waitressing only, gives the impression that some women were excluded because they were associated with prostitution. In Belgium, the socialist union of garçons de café, established in Brussels in I 89 I and subsequently affiliated to the Parti ouvrier belge, strived to abolish women's work wherever and whenever men could be employed instead. Referring to this episode as a mistake, the socialist waiters' union created a section of serveuses de brasseries in I 9 I $2 .{ }^{38}$ The latter suggests that in Brussels waitresses were mainly employed in brasseries, which is implicitly confirmed by a discussion in the postwar period with regard to women's night work: the serveuses de brasseries were the main preoccupation of both employers and unions. ${ }^{39}$

\section{SERVING STAFF'S REMUNERATION IN WESTERN EUROPEAN CITIES}

How old and widespread was the arrangement by which customers' tips paid waiters" "wages", who in turn were required to pay a fee in order to be allowed to work? In Paris quite a few waiters appeared to work for tips only, at least from the i 840 s onwards. The journal L'Atelier stated in I 846 that the majority of waiters had no wage. ${ }^{40}$ Louis Lacour de La Pijardière, a French librarian and archivist, observed in 1856 "even in the most mediocre establishments of Paris fixed wages are not given to the waiters any more", ${ }^{\mathrm{I}}$ suggesting that the disappearance of a fixed wage was a rather recent phenomenon, which had occurred earlier in upmarket venues than in more modest establishments. In I 86I the journalist Alexandre Weill reported that waiters' tips were collected in le tronc, ${ }^{42}$ and subsequently shared with the owner, who would not pay his garçons, allegedly in opposition to practices in Germany and Britain. ${ }^{43}$

Not only were waiters not paid, they had to pay the owner in order to be allowed to work, while the content of le tronc was used to a large extent to finance all sorts of general expenses, from broken glassware (la casse)

38. "Les garçons de café”, Le Peuple, 2 I July i895; “Avis aux serveuses”, La Serviette, I (I9I2), p. I.

39. Comité national de l'industrie des hôtels, restaurants et débits de boissons. Séance du 26 Avril 1924. The thematically ordered minutes are kept at the National Archives of Belgium (Brussels).

40. "De quelques mauvais usages", L’Atelier. Organe spécial de la classe laborieuse, 6 (I 846), p. 252.

4I. Louis Lacour de La Pijardière, Les garçons de café et de restaurant de Paris (Paris, i 856), p. I 8. All translations are mine.

42. The tronc is a wooden box in which the tips were collected. The tronc (or variants of that word) was also adopted in other countries.

43. Alexandre Weill, Paris inhabitable: ce que tout le monde pense des loyers de Paris et que personne ne dit (Paris, I861), pp. 38-39. 
to the wages of the wine waiter. ${ }^{44}$ In the 1870 , quite a few Parisian cafés abandoned le tronc and replaced it with a system of tokens: each morning the waiter had to buy a certain number of tokens, which he would then return successively over the day according to the number of drinks sold, but 5 to ro per cent of what he paid was withheld by the owner in order to finance les frais, or general expenses. ${ }^{45}$ The waiter's contribution had to be paid regardless of the actual tips he received. A customer who did not tip therefore cost the waiter money. In restaurants le tronc was still in use. ${ }^{46}$

Waiters working for tips only, owners of restaurants and cafés using tips to pay for general expenses, and waiters paying a fee to be allowed to work, were not limited to Paris. In France's other major cities, too, the patrons de café did not pay their waiters and held back part of the tips. ${ }^{47} \mathrm{In}$ the beginning of the twentieth century, the pourboire was called the pourboire-salaire because the tip could no longer be considered a gratuity, since it had largely or completely replaced the wage. ${ }^{48}$ An increasing array of expenses appeared to be financed by tips: not only la casse but also ink, stationery, pens, newspapers, and matches were paid for in this way. ${ }^{49}$ Some garçons also paid the window cleaners, the floor polishers, the caporal, who ran errands, and their omnibus, or "the waiter of waiters", ${ }^{\circ}$ a young lad who helped them to set and clear the table, and to do le mastic, the general cleaning up of the place after customers had left or before they arrived. ${ }^{\mathrm{I}}$ However, despite all these expenses, waiters who relied on customers' tips took more money home than their colleagues (subordinate waiters and

44. C. Joliet, "Les impôts volontaires”, Le Figaro, I 3 and I 7 July I 856 ; "Les chasses du Figaro", Le Figaro, 22 June i 865. See also "Le pourboire”, Le Rappel, 3 I July i 884; Herman Kuhn, "Paris. Speisehäuser und Nahrung”, Der Heimgarten. Ein Haus- und Volksblatt mit Bildern, 2 (I 865), p. 76; [Anon.], Mémoires d'un garçon de salle. Actualité visant la corporation des garçons de salles et son affranchissement par un ancien maître d'hôtel des premières maisons de Paris (Paris, I884), pp. 21-26; Joseph Barberet, Le travail en France: monographies professionnelles. Tome 7. Débitants de boissons (Paris, I890), pp. 399, 417-418, 433-435.

45. "La question des bureaux de placement", Le Temps, I2 August I886; "La question du pourboire", La Presse, 3 I January i 890.

46. "Les frais", Le Rappel, 28 August 1904.

47. "Les garçons de café”, Le Rappel, Io November I 898. In I 898, I903, and 1907, Jules Coutant, socialist député of the département Seine, filed a proposal prohibiting waiters' employers from taking advance payments known as frais, but it was only by the laws of i9 July 1933 and 2 April 1937 that these matters were dealt with. See Confédération générale du travail, Fédération nationale des travailleurs de l'alimentation, Chambre syndicale des limonadiers-restaurateurs et assimilés de Paris, Le rapport Chambon sur la suppression des frais. Les salaires fixes. Le repos hebdomadaire (n.p., n.d.), p. 9; Bach, Le pourboire-salaire, pp. 199-212; André Delmas, La réglementation du pourboire (Aix-en-Provence, I94I), pp. 25-50.

48. Bach, Le pourboire-salaire, pp. I I, I3.

49. Ibid., p. 42.

50. "The Tipping Question in Paris", Freeman's Journal, 3 August I 897.

5. Bach, Le pourboire-salaire, p. 4I; "Les frais", Le Rappel, 28 August I904. 
servers working in restaurants at the lower end of the market) who were paid a fixed wage. ${ }^{52}$

At least from the i 880 os on, Brussels waiters' working conditions were fairly similar: garçons de café et de restaurants received no wage, had to pay to be allowed to work, and financed through their tips the wages of other staff members as well as la casse, various other expenses, and the cleaning of the premises. ${ }^{53}$ In Amsterdam, fixed wages seemed to be somewhat more widespread than in Paris and Brussels. While in many cafés waiters received no wage, bigger establishments, where most waiters were employed, did pay a fixed wage. Often, however, the fixed wage was insignificant and was entirely devoted to paying for helpers, cleaning, and breakages, although the latter seemed to occur less than in Paris and Brussels. Making waiters pay for being allowed to work became increasingly common, and on the eve of World War I a rising number of Dutch establishments that used to pay fixed wages no longer did so. ${ }^{4}$ Meanwhile, in Germany, in I 89382.5 per cent of waiters were still in receipt of a small fixed wage. ${ }^{55}$ However, as in the Netherlands, the number of waiters receiving a fixed wage seemed to decline: while in r 89376.9 per cent of café waiters in Germany had a small fixed wage, on the eve of World War I only some 20 per cent did so. ${ }^{56}$

In contrast with Paris, Brussels, and Amsterdam, where customers were served by one waiter, Vienna had a Dreikellnersystem, consisting of three waiters: the Speisenträger, who served the customers, the head waiter (called Zablkellner or Markör), who appeared when it came to paying the bill, and the Piccolo, who dressed the table, served water, and ran errands. ${ }^{57}$

52. Bach, Le pourboire-salaire, pp. $3^{8-43}$.

53. Mémoires d'un garçon de salle, pp. 45-47; "Garçons et patrons", Le Peuple, i 8 June i 890; Franz Mahutte, Bruxelles vivant (Brussels, I 891), p. 22; "Les garçons de café et les lois ouvrières", Le Peuple, is November I 896; Chambre des Représentants, Annales parlementaires de Belgique, 7 March I899, p. 767; 22 March I899, pp. 903-907.

54. N., "Kellners en het fooienstelsel”, Nieuws van den dag, 25 December I 893, pp. 19-20; S.-Z., "Kellners", Algemeen Handelsblad, I7 June I903, p. I0-I I; "Kellners-Vereenigingen", Rotterdamsch Nieuwsblad, I I March 1904, p. Iо; De toestand der bedienden in het hotel- en cafébedrijf te Amsterdam, pp. 10, 21, 22, 27, 28; J.G. van Heusden, De urgentie van sociale wetgeving voor het hotel-, café- en restaurant-bedrijf (Amsterdam, I914), pp. I4, I9; Eringaard, Kellners, pp. I 8, 2 I; Aan alle geëmployeerden in het logement- en koffiehuishoudersbedrijf (The Hague, 1909), p. 3. 55. Kommission für Arbeiterstatistik, Arbeits- und Gebalts-Verbältnisse der Kellner und Kellnerinnen, pp. $27,60,62,64,68$, and 74 . While in the north of Germany 80.5 per cent of waiters had a fixed wage, the corresponding figure in the south of the country was 9I.4 per cent; 83 per cent of waiters employed in a hotel, 82.9 per cent of waiters working in a restaurant, and 76.9 per cent serving in a café had a fixed wage.

56. On the eve of World War I, 2 I.5 per cent and 24.2 per cent of the Revierkellner in Berlin and other German cities respectively had a fixed wage. See Verband der Gastwirtsgehilfen, Statistische Erhebungen betreffend die Lohn- und Arbeitsverbältnisse der Café-Angestellten (Berlin, I9I4), p. 8.

57. "Pariser Austellungsbriefe", Das Vaterland. Zeitung für die österreichische Monarchie, 7 May I867; "Schnüren die Wiener Kellner?", Arbeiter-Zeitung, I9 June 1914, p. 5; "Für das 
Headwaiters paid proprietors large sums to obtain a position. ${ }^{58}$ Most Zablkellner had a low fixed wage and the sale of cigars added to their income, but their tips had to finance their subordinates' wages, newspapers, and breakages. ${ }^{59}$ In the middle of the r870s, the Wiener cafe and the "Viennese" division of labour were introduced in Berlin. ${ }^{60}$ The tips of Berlin's Zablkellner paid the wages of the Zuträger, waiters who served but were not allowed to handle money. Revierkellner, who could serve and handle money as well, had a small wage. The tips of Zablkellners and Revierkellners financed 7I.3 per cent of the Zuträger's wages. ${ }^{61}$ As in other capitals, Berlin waiters paid a share of general expenses: Bruch (breakages), lost items, Bonbücher, on which the orders were written down, toothpicks, charwomen, etc. ${ }^{62}$

The hierarchical "Viennese" division of labour was also applied in some London restaurants. Apart from the establishments where waiters worked on equal terms, in that they all lived on tips, had to pay for being allowed to work, and financed a share of general expenses, ${ }^{63}$ there were places where the headwaiter received all the tips and paid the subordinate waiters a fixed wage ${ }^{64}$ Here, too, fixed wages were subject to stoppages for breakages and mistakes. Waiters were also charged for the most unlikely reasons: for their use of a knife and fork, a "prescribed" beaker for drinking, the buttons on their livery, and more. ${ }^{65}$

Allegedly, female serving staff received a fixed wage more often than their male colleagues, because they collected fewer and less generous tips. ${ }^{66}$ However, there are no indications that gender played a decisive role in their

Einkellnersystem”, Fremden-Blatt, 2 I June 1914, p. I0; "Reformen des Bedienungswesens in Österreich”, Fremden-Blatt, 23 May i 915 , p. 39.

58. Labor in Europe: United States Consular Reports (Washington, I885), p. I 216.

59. "Trinkgelder", Morgenblatt für gebildete Leser, 50 (1856), p. 93; Nieder-Österreichs Handels- und Gewerbekammer, Die Arbeits- und Lohnverhältnisse in den Fabriken und Gewerben Nieder-Österreichs (Vienna, 1870), pp. 87-89; Zentral-Organisation der Hotel-, Gast-, und Kaffeehaus-Angestellten Österreichs, Die sozialen Verbältnisse der Kaffeehaus-Angestellten. Eine Gefahr für das Kaffeehaus besuchende Publikum (Vienna, I9I3), pp. 19-20.

6o. Internationale Union der Hotel-, Restaurant- und Café-Angestellten, I. Internationale Konferenz, 1908 (Berlin, I908), p. 25.

6I. Das Berliner Caféhausgewerbe, pp. 26-3 I.

62. The examples given in the following pamphlets largely refer to Berlin: L. Ebert and R. Hoffmeyer, Das Trinkgeld und die wirtschaftliche Lage der Kellner und Berufsgenossen (Berlin, I892), pp. 2 I-26; Max Schippel, "Die Lage der grossstädtischen Kellner”, Die Neue Zeit, 9 (I890/9I), pp. I03-I04; Karl Oldenberg, Der Kellnerberuf. Eine sociale Studie (Leipzig, I893), pp. I 3 -1 5 .

63. "Waiters", Yorkshire Evening Post, I 3 April г 891. See also notes 58-62.

64. "Waiters on the War Path", Daily News, 26 November I889. See also "Restaurant Management”, The Graphic, I7 March I883; “The Tipping System”, Reynolds's Newspaper, 30 July i 893 .

65. "Sweated Waiters", Reynolds's Newspaper, I3 October I 895.

66. See the appraisal in the following North American manual: Jessup Whitehead, The Steward's Handbook and Guide to Party Catering (Chicago, IL, I903), p. 207. 
remuneration. The Brussels serveuses de brasseries did not receive a fixed wage and had to pay their daily share of les frais, just like their male colleagues. The 1893 enquiry into the condition of German serving staff mentioned before reveals that 82.5 per cent of waiters and 79 per cent of waitresses were in receipt of a small fixed wage. ${ }^{67}$ Like their male counterparts, the waitresses of Munich and the Grand Duchy of Baden were given several chores or they had to pay helpers instead. ${ }^{68}$ While the waitresses of the Parisian Bouillon Duval chain of restaurants and London's tearooms had small fixed wages (with deductions for breakages), their colleagues at the Munich Prunk-Cafés and the Bouillon Duval restaurant at the World Exhibition in Paris in 1878 did not receive fixed wages, because takings in tips were expected to be high. ${ }^{69}$

Overall, the front-of-house workforce in European restaurants and cafés can be subdivided into two groups: waiters and waitresses who were paid no fixed wage, or hardly any, and whose tips had to finance a part of their employers' general expenses (including the fixed wages of their subordinates and helpers) on the one hand, and the workers who were paid a fixed wage on the other hand, namely subordinate serving staff and people employed in establishments at the lower end of the market. Waiters' unions and pamphlets denouncing the abuses associated with the tipping system were interested mostly in the fate of the former: the waiters and helpers who received a fixed wage but no tips were perceived as a cost that the tip receivers had to bear. $^{70}$

\section{AN EVIL ORIGINATING ABROAD?}

It is tempting to point to France, and Paris in particular, as the places where the practices associated with the tipping system in hospitality originated.

67. Kommission für Arbeiterstatistik, Arbeits- und Gebalts-Verbältnisse der Kellner und Kellnerinnen, pp. 62, 68, and 74;8 3 per cent of waiters employed in a hotel, 82.9 per cent of waiters working in a restaurant, and 76.9 per cent serving in a café had a fixed wage.

68. Peter, Zur Lage der Kellnerinnen im Grossherzogtum Baden, pp. $25-38$; Arthur Cohen, "Die Lohn- und Arbeitsverhältnisse der Münchener Kellnerinnen”, Archiv für soziale Gesetzgebung und Statistik (1892), pp. 97-I 3 I, I07-I I 2.

69. "La grève des femmes”, La Lanterne, 2 I July I 878; “L'exposition”, La Lanterne, I 8 July I 878 ; "The Strikes in France", The Standard, I 8 July i 878; "Strike of French Waitresses", Dundee Courier and Argus, 2 August i 878; Bird, The First Food Empire, pp. 44-46; "Waitress's Wages", Pall Mall Gazette, i9 November I 895; "The Teashop Girl”, Yorkshire Telegraph and Star, 2 April 1913; "Lyons and J.P. Restaurants", Daily Herald, 5 May 1914; Cohen, "Die Lohn- und Arbeitsverhältnisse der Münchener Kellnerinnen”, p. I07.

70. See, for instance, how Belgian waiters' organizations focused on the problems of waiters and not on the working conditions of the commis, whom they paid directly or through le tronc: "En marche vers la suppression des frais", "Clients des hôtels, cafés, restaurants et brasseries", "Aux travailleurs des hôtels, cafés, restaurants et brasseries", La Serviette, 2, 3, and 5 (I9I 2); "Notre but", Le Combat, I (I913); Journal de l'Union syndicale, numéro spécial (I913), Journal de l'Union syndicale, numéro spécial (1914), "Immoralité patronale"; Journal de l'Union syndicale, June (I9I4). 


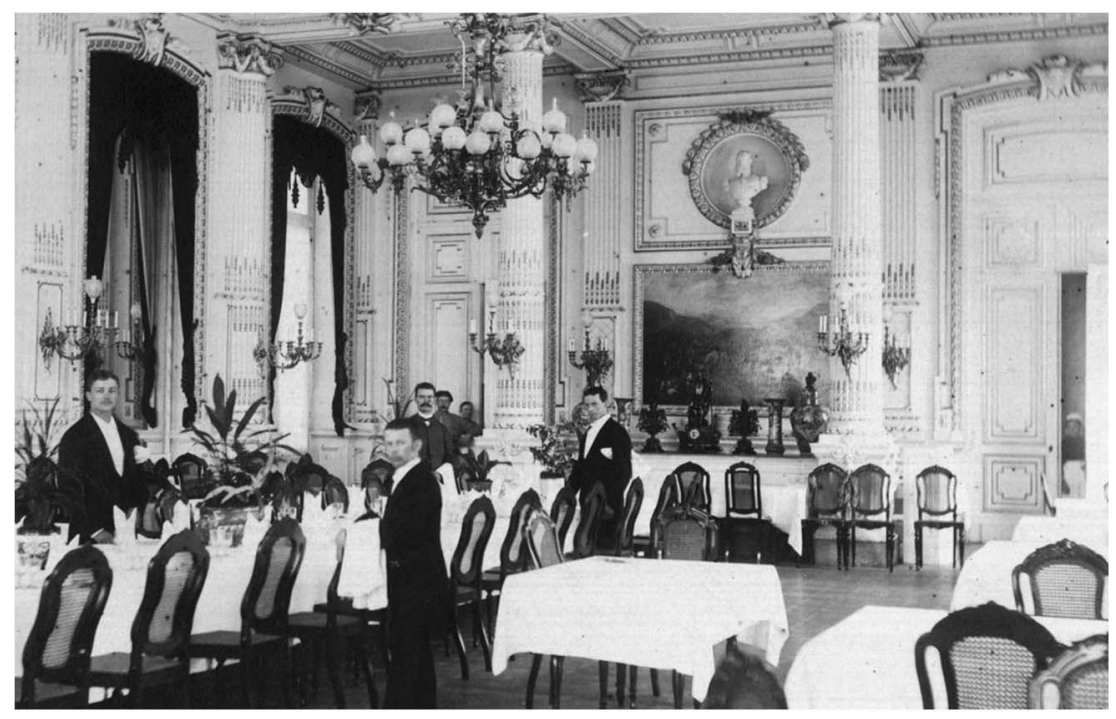

Figure I. Waiters in the casino at Spa, a Belgian holiday resort that attracted a great many foreign serving staff.

Library of the University of Ghent. Used with permission.

While French commentators cited no foreign examples, their counterparts in other countries suggested that France, and Paris in particular, played a predominant role in their international proliferation. In I 89 I the Brussels newspaper Le Soir, for instance, blamed French waiters for the worsening of Brussels waiters' working conditions. Before the Franco-Prussian War of I 870-I87I, the article argues, Brussels waiters were paid BEF 30-60 per month; they received tips, but these were negligible. However, when French waiters fled their country and came looking for work in the Belgian capital, they allegedly offered to pay their employers a droit de tablier, thus outbidding their Belgian colleagues. ${ }^{7 \mathrm{I}}$ A Dutch pamphlet published in 1903 had no doubts as to where working conditions in the hospitality sector originated: "the plague", as it was called, came from Paris, and strangers had imposed it on the Dutch. ${ }^{72}$

Jacob Eringaard, author of another Dutch pamphlet, associated the custom of waiters having to pay for being allowed to work mostly with Paris

71. "Les garçons de café”, Le Soir, 30 May i891. See also the following observation: "Twenty-five years ago tips were hardly known. Publicans paid their staff and did not leave this to the customers"; "Chronique bruxelloise", Le Soir, 29 September 1904.

72. Mars, Het fooienstelsel veroordeeld! De verdwijning daarvan in aantocht (The Hague, 1903), pp. Iо, 24 . 
and other foreign cities. ${ }^{73}$ Max Schippel and Karl Oldenberg, who studied working conditions in Germany, pointed to the fact that in some cases the Wirt wanted to be paid before waiters started their workday; they both associated this practice with Paris. By emphasizing that the latter occurred not only in Paris, Brussels, and other cities in France and Belgium but in Germany, too, Oldenberg implicitly traces the origin of these practices to the neighbouring countries. ${ }^{74}$ Significantly, the fact that the box in which the tips were collected was also often designated as le tronc, even outside France, would suggest a French origin.

There is no doubt that France, and Paris in particular, played an important role in the hospitality sector. Paris was not only regarded as the gastronomic capital of the world, the city also functioned as a major employer and transit centre in the sector. ${ }^{75}$ Working in Paris for a while was perceived as an essential phase in a waiter's training, while the French Riviera was an important destination for an international contingent of seasonal workers. Of course, French hospitality personnel also worked in neighbouring countries, so it would not be surprising that arrangements adopted in French cities found their way to the hospitality sector abroad.

The references I found for London, however, undermine the hypothesis that a single European country or city could be held "responsible" for the practices associated with the tipping system. In this case, working for tips only and paying a fee for being allowed to work were not associated with a specific geographical origin, but rather with the non-French foreign hospitality workers who allegedly introduced them. Not France and Paris, but the German, Swiss, and Italian serving staff and their "motives" and "characteristics" were passionately discussed. It seems that from the late I 880 s onwards the practices associated with the tipping system and the presence of foreign waiters became discursively linked. ${ }^{76}$

The American periodical Littell's Living Age wrote in 1886 that the old-fashioned British waiter was becoming a rarity since "waiters are now imported, like so many of the dishes they serve from abroad"..$^{77}$ A restaurant was referred to where all foreign waiters paid a fee for their position, but they did not grumble because they made money fast.

73. Eringaard, Kellners, pp. I8, 2 I.

74. Oldenberg, Der Kellnerberuf, p. I4; Schippel, “Die Lage der grossstädtischen Kellner”, p. 104 .

75. Peter Scholliers, "Anonymous Cooks and Waiters: Labour Markets and the Professional Status of Restaurant, Café and Hotel Personnel in Brussels, I840s-1900s", Food E History, 2 (2004), pp. I37-I65; Patricia Van den Eeckhout, "Cooks and Waiters on the Move: The World and International Exhibition in Ghent, I9I3, as a Destination for Hospitality Workers”, Food E History, I I (2013), pp. 287-316.

76. "Waiters on the War Path", Daily News, 26 November I 889; "English Versus Foreign Waiters”, Pall Mall Gazette, ro October I 889; "Waiters”, Yorkshire Evening Post, I 3 April I89 I. 77. “About Waiters”, Littell's Living Age (1 886), pp. 8 1 3-8 I6, 8 I 4. 
Allegedly, the majority of London waiters were foreigners and they appeared to be far less exigent than their British counterparts: "For small copper coins they will bow where Saxons will only bow to silver." ${ }^{8}$ Foreign waiters were not just prepared to work for tips only, they actually paid fees to get a position, Charles Booth stated in the I 890s: "Unlike his English confrère, the German, Swiss, or Italian waiter usually receives no wages, but, on the contrary, has to pay his employer, such payment not uncommonly taking the form of a percentage of $6 d$ [pence] or more in the pound on his gross takings." ${ }^{\prime 9}$ Foreign waiters' alleged subservience was explained by their eagerness to learn English and their expectation that their increased language skills and savings would enable them to find a lucrative position in their own country or even start their own business. ${ }^{80}$ "When they have learned English they go back to their own countries and become prosperous", so a representative of an English waiters' association concluded. ${ }^{81}$

In the British sources, neither France nor Paris were allocated a particular role in the establishment and dissemination of remuneration practices, but it is also doubtful that the latter were introduced into the British Isles as a result of the labour migration of waiters from the continent as such. It appears that the practices associated with foreign itinerant waiters from the I 880 s on had been identified long before the foreigners' presence became an issue. As early as 1823 the Leeds Intelligencer observed: "[i]t is a notorious fact, that waiters, chambermaids, postboys and other servants at inns, instead of receiving wages, actually pay the master or mistress for their places". ${ }^{82}$ In 1863 the Glasgow Daily Herald complained not only about the tipping system but also about the restaurateur compelling "his servants to pay him for the privilege of working under him", without reference to foreign waiters. ${ }^{83}$ In light of the above, it can be concluded that the practices associated with the tipping system cannot be attributed to a clear geographical “origin”.

78. “Our Foreign Waiters”, Belfast News-Letter, 26 December I 888. See also Panikos Panayi and Stefan Manz, "The Rise and Fall of Germans in the British Hospitality Industry, c. I880-1920", Food E History, I I (2013), pp. 223-242.

79. Booth, Life and Labour of the People in London, p. 232.

80. The Mercury, is May i89i; “The Evolution of a Waiter", Yorkshire Evening Post, I March I 894 .

81. "Working for Nothing", Daily Express, i i May i905.

82. "On Servants' Vails", Leeds Intelligencer, 20 February I 823.

83. "A Penny for the Waiter", Glasgow Daily Herald, 7 September 1863. Other examples from the 18505-1880s in which no link with foreign waiters is made: "Gratuities to Hotel Servants", Chester Chronicle, is March I851; "The Feeing of Waiters", The Graphic, I9 September 1 874; "London Correspondence”, Western Mail, 26 May i 877; "London Gossip", Nottingham Evening Post, 3 January 1879; "Tips”, Derby Mercury, 24 December I879; "The London Waiter", The Cornishman, 27 January i88I; "London Notes", Derby Daily Telegraph, io October 1883 . 


\section{BOARD AND LODGING}

While both tip receivers and earners of fixed wages could be encountered in all the European cities I have discussed, granting male restaurant and café servers full board and lodging seems to have been typical of Germany and Austria. In the case of waitresses this was widespread also in other countries. In Germany in I 89364 per cent of waiters and 87.9 per cent of waitresses enjoyed full board and lodging. ${ }^{84}$ Café and restaurant waitresses were given board and lodging as often as hotel waitresses, but hotel waiters were more likely to be given board and lodging than restaurant and café waiters. Regional differences have also to be taken into account: in Munich 57.4 per cent of waiters and 88.4 per cent of waitresses received board and lodging, but in Berlin only 20.4 per cent of waiters and not a single waitress did so. Berlin's Wiener cafés did not accommodate their employees. ${ }^{85}$ In Vienna, board and lodging appeared to be quite common for serving staff in general. ${ }^{86}$ The frequent occurrence of board and lodging in Germany and Austria could be an indication that in these countries serving staff were still perceived as domestic servants. German waiters resented association with the latter, though, and descriptions abound of the appalling conditions in which they were lodged. However, accommodating one's staff became less common, because rising urban rents made space scarce and expensive. ${ }^{87}$

In London, Brussels, Amsterdam, and French cities, it does not appear to have been customary for waiters to have free lodging, but a meal was often part of their remuneration. Waitresses, however, appeared to enjoy board and lodging more often: an enquiry into the condition of waitresses in British cities in 1893 reported that 77.8 per cent were provided with board and lodging, while an enquiry into the condition of waitresses in Dutch cities in I9I 8 found that 53.3 per cent (of whom only 22.6 per cent were employed in hotels) were lodged by their employers. ${ }^{88}$

Serving staff often fiercely criticized their meals. In Germany, leftover food was the main ingredient of the so-called Kellnergoulasch (waiters' stew). ${ }^{89} \mathrm{~A}$ letter to the editor describes the staff's meal at a London restaurant: "The dinner given in this establishment consists of all the odds and ends from the

84. Kommission für Arbeiterstatistik, Arbeits- und Gehalts-Verbältnisse der Kellner und Kellnerinnen, pp. 62, 68.

85. Ebert and Hoffmeyer, Das Trinkgeld, p. 22.

86. Poetzsch, Geschichte der Zentralorganisation der Hotel-, Gast- und Kaffeehausangestellten, pp. I IO-I I I.

87. Verband der Gastwirtsgehilfen, Statistische Erhebungen betreffend die Lohn- und Arbeitsverbältnisse der Café-Angestellten, p. I I.

88. Orme, "Conditions of Work of Barmaids, Waitresses", p. 204; Anna Polak, Buffetjuffrouwen en bediensters in het hôtel-, café- en restaurantbedrijf (The Hague, I9I 8), pp. 8, 46 .

89. Ebert and Hoffmeyer, Das Trinkgeld, pp. I 8-2 I; Cohen, "Die Lohn- und Arbeitsverhältnisse der Münchener Kellnerinnen”, pp. I I 3-I I4. 
kitchen (fish, meat, vegetables, etc.), as well as the leavings on the customer's plates from the previous day, stewed together and served in one large bowl or 'foot-bath'." ${ }^{\circ}$ Even in renowned restaurants, employees were often badly fed. The kitchen chef sold the tastiest leftovers to third parties, and what was left was of inferior quality, or it was invariably the same: boiled meat, for instance, was served to the waiters day in and day out, because it was a by-product of the preparation of customers' consommé. Some serving staff preferred to have a

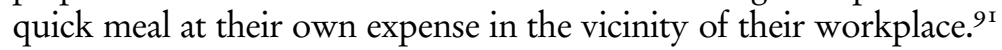

Overall, waiters' unions were opposed to board and lodging as part of staff remuneration: the cash value of this payment in kind was often overrated, while it was feared that living at the employers' properties prevented the development of class-consciousness, either as a result of identification with the employer or with the status of domestic servant. ${ }^{92}$

\section{SERVING STAFF AS LEASEHOLDERS, SUBCONTRACTORS, AND SWEATERS}

Waiters and waitresses paying their helpers a fixed wage and financing all sorts of general expenses of a business: these responsibilities are not usually included in employees' job descriptions. How did contemporary observers characterize the position of serving staff?

Oldenberg associated waiters with leaseholders when he spoke of a waiter who paid eine Pacht (rent), which he called the "Pariser System", ${ }^{93}$ as did Eringaard when he compared the waiter with the leaseholder of a buffet who paid the local authorities for a space in the market square. For him, even a small money wage did not change this landlord/leaseholder relationship. ${ }^{94}$

Other commentators emphasized the role of waiters as intermediaries in the sale of their employers' products: in Cohen's study of waitresses in Munich, waitresses had to pay up front for a given number of beers and buns, while in cafés they paid for a certain number of coffees before their workday started. They therefore functioned as subcontractors for the owners' products. In most Munich establishments waitresses did not even deal directly with the owner, but with a waiter, the Schänkkellner (barman), who had the bar in Regie, which meant effectively that he had subcontracted the selling of beer. ${ }^{95}$ In other parts of Germany, too, serving staff sold beer,

90. “Sweated Waiters”, Reynolds's Nerwspaper, 6 October I895.

91. "Les frais", Le Rappel, 28 August 1904; "La condition des garçons de café”, Le Rappel, 23 April 1907; Léon and Maurice Bonneff, La classe ouvrière (Paris, I9 I 2), pp. I09-1 IO.

92. G. Robert, "Dans les hôtels", L'ouvrier syndiqué, I October I9I3; Poetzsch, Geschichte des Zentralverbandes der Hotel-, Restaurant-, und Caféangestellten, pp. 72-73.

93. Oldenberg, Der Kellnerberuf, p. I4.

94. Eringaard, Kellners, p. 17.

95. Cohen, “Die Lohn- und Arbeitsverhältnisse der Münchener Kellnerinnen”, p. I I 5 . 
liquor, and cigars or ran the buffet for their own account. ${ }^{96}$ In the Grand Duchy of Baden waitresses had to buy a certain number of breakfast buns: if they did not manage to sell them all, they (and not their employer) were stuck with them. According to Peter, waitresses were increasingly cast as "balbselbständige [...] Mittelsperson", semi-independent intermediaries. ${ }^{97}$ For him, tips were part of this transaction of subcontracting: the waitress leased the opportunity to collect tips at her employer's premises, and in return she served the customers and kept the place clean. Serving staff paying their helpers and/or a fee for being allowed to wait on the tables might also be part of the deal.

While according to some commentators these conditions were not necessarily bad for the serving staff (the Parisian waiter is not in the "ordinary position of a workman", "he is in some sense a partner", the Evening Telegraph stated), ${ }^{9}$ others, like Max Schippel, acknowledged how this could lead to self-exploitation. He characterized waiters as being "balb Lohnsklaven, balb Filialisten ibrer Wirthe" (half wage-slave, half franchise-holder from the owner). Waiters sold the products of their employers for a profit, but it was the customer who decided how high the profit (the tip) would turn out to be. According to Schippel, Paris was the place where this perverse system could be encountered in its most extreme form. ${ }^{99}$

Since most of my sources appear to represent social conditions from the point of view of the tip-receiving serving staff, the latter were seldom cast as intermediaries who profited from the selling of their helpers' labour. Only head waiters and so-called boss waiters were sometimes associated with sweating, an exploitative form of subcontracting. ${ }^{100}$ Yet not only headwaiters wanted things to remain as they were; all the serving staff, even the lowest in rank, hoped to benefit and strove to be part of the scheme: in I 889 an organization requiring headwaiters to hire English serving staff exclaimed: "The middleman system must continue with us" (instead of foreign waiters). ${ }^{\text {IOI }}$ Also a commentator who characterized the system under which waiters operated as marchandage, an exploitative form of subcontracting abolished (in principle) in France in 1848 , acknowledged its merits: serving staff who survived this struggle for life were the hospitality entrepreneurs of tomorrow. ${ }^{\mathrm{IO2}} \mathrm{By}$ emphasizing the exorbitant sums offered

96. Kommission für Arbeiterstatistik, Arbeits- und Gebalts-Verbältnisse der Kellner und Kellnerinnen, pp. I 20, I23.

97. Peter, Zur Lage der Kellnerinnen im Grossherzogtum Baden, pp. 27, 38.

98. Evening Telegraph, 7 November 1902.

99. Schippel, “Die Lage der grossstädtischen Kellner”, p. 146.

ı००. "Waiters on the War Path", Daily News, 26 November I 889; "Waiters Object to Tips", Nottingham Evening Post, Io August 1903.

ıо . Quoted from "English Versus Foreign Waiters”, Pall Mall Gazette, i० October i 889.

I02. "La question du pourboire et le marchandage", L'Indépendance belge, I August I 897. 
for lucrative positions in upmarket restaurants, cafés, and beer halls, some commentators contributed to the myth of "the affluent waiter". ${ }^{103}$

\section{TIPS AND THE “NORMAL WAGE” - A PERMANENT MÊLÉE BETWEEN EMPLOYERS AND SERVING STAFF}

The emergence of practices associated with the tipping system was also explained by pointing to employers' attempts to limit waiters' income. The Encyclopédie socialiste, syndicale et coopérative remarked that if the sum collected by tips was considered to be "too high", it was reduced so as to pay waiters a "normal wage". ${ }^{\circ} 4$ The newspaper Le Rappel agreed with the idea that what the waiter gets is what his employer has in mind as a proper wage. ${ }^{105}$ In his book on labour in France, Barberet stated that if waiters were to be paid the entire content of le tronc, it would procure them a wage "which the publican judges as too high". ${ }^{106}$ Without the charges, a waitress in Munich would have a higher income than her employer, according to Cohen, quoting the defendants of existing practices. The liberal economist Paul Leroy-Beaulieu was also thinking of a "normal wage" when he tried to explain why, in a lot of cases, tips had replaced wages and why employers used tips to pay for their general expenses. He argued that if tips were recurrent and more or less predictable, it was normal that they should be taken into account when calculating workers' remuneration. ${ }^{107}$ Activities necessitating similar effort and ability should be rewarded similarly, and consequently, if the prospects for receiving tips were good, the fixed wage would be low and vice versa. In the American journal Gunton's Magazine it was argued that since workers' wages fluctuated round the cost of living, an additional source of income (tips) inevitably meant that the other source of income (wages) would decrease. ${ }^{108}$

Of course, reducing waiters' earnings to a level considered as a "normal" wage was not necessarily an end in itself. It also enabled entrepreneurs in hospitality to make ends meet. As a result of aggressive competition, even the most humane employer had no choice but to

I03. C. Joliet, "Les impôts volontaires”, Le Figaro, I 3 July i 856 ; T.W. Scott, How to Travel (New York, I 888), p. 91; "Affluent Waiters”, Daily Express, 24 October 1904. See also note 80.

104. Encyclopédie socialiste, syndicale et coopérative de l'Internationale ouvrière (Paris, I9I3), VI, pp. $25-26$.

I05. "Le pourboire", Le Rappel, 8 August I 888.

106. Barberet, Le travail en France, p. 435. See also H. Grenier, “Le bachich”, L'ouvrier syndiqué, I March I 898 .

107. Paul Leroy-Beaulieu, Traité théorique et pratique d'économie politique (Paris, 1914), II, pp. $627-628$.

I08. "Economic Effects of Tipping”, Gunton's Magazine of Practical Economics and Political Science, July 1896, pp. I3-19, I7-18; see also Whitehead, The Steward's Handbook and Guide to Party Catering, p. 199 . 
exploit his staff, the Dutch hospitality union argued. ${ }^{109}$ Due to the exponential growth of cafés in Paris in the last quarter of the nineteenth century, a share of the tips had to pay the cafetiers' expenses, because price increases were out of the question. ${ }^{I 10}$ Although pleas against tipping were a very popular genre, customers had apparently fewer problems with the gratuities they gave of their own free will than with price increases. The information with respect to Vienna confirms the spectacular development of the hospitality industry (from I,429 businesses in I 830 to 6,038 in I894); Weigl even evokes a Gaststätteninflation, an inflation of hospitality establishments. ${ }^{\text {II }}$

The tipping system was also linked to urban rents. In I 860 the French journalist Alexandre Weill blamed the high level of Parisian rents for the tipping system, and for employers demanding a share of tips: without it they would not be able to rent the premises of a café in the centre of the French capital. ${ }^{\text {II2 }}$ In 1908 the German social-democratic hospitality workers' union claimed the catering sector was able to pay much higher rents than other businesses thanks to the existence of tips. ${ }^{113}$ Sheer greed was also a popular explanation advanced in union sources and newspaper articles: entrepreneurs in hospitality were presented as bold and shameless businessmen who, in contrast with their colleagues selling shoes or clothes, managed to make the public pay their workers. Tipping was a nuisance, but as it was entrenched in European customs cafetiers and restaurateurs could exploit it to their own benefit.

Apparently, contemporary commentators had contrasting views on the tipping system and associated practices: on the one hand serving staff were perceived as subcontractors who could aspire to make a "profit"; on the other hand they were cast as workers who were destined to earn a "normal" wage, paid either by their employer or the customer. In fact the two views were not incompatible. The situation of serving staff can be compared to the industrial labourer working in a piecework and premium system. In the latter the employer exploited workers' ambition to make a "profit", but despite the fact that it incited them to increase their output and thus their wages, employers did not tolerate workers earning "too much". The latter was interpreted as proof that the piecework rate had been set too high or

I09. Gladiator, "Inzake het bedanken van Dr. Eringaard", De geëmployeerde. Officieel orgaan van den Nederlandschen Bond van geëmpl. in het logement- en koffiehuishoudersbedrijf, Is March and I April 1909.

I Iо. "La question du pourboire et le marchandage”, L'Indépendance belge, i August I 897.

I I I. Andreas Weigl, “Gaststätten: zur Ökonomie der Geselligkeit”, in Günther Chaloupek, Peter Eigner, and Michael Wagner (eds), Wien Wirtschaftsgeschichte 1740-1938. II: Dienstleistungen (Vienna, 1991), pp. 1044-1045, 1085.

I 2 . Weill, Paris inhabitable, pp. 38-39.

I 13. Das Berliner Caféhausgewerbe, pp. I2-13. 
that the increased output was primordially the product of the employers' investment, and the piecework rate was consequentially reduced. ${ }^{\mathrm{I} 4}$ Arguing that waiters' tips were largely the result of their businesses' excellent location and luxurious furnishing, owners of upmarket restaurants and grand and busy cafés thought it justified to "skim" waiters" gratuities. ${ }^{\text {IS }}$ Expecting to receive generous tips, serving staff paid the required charges, thus reducing the "profit" they hoped to make: at the end of the day they went home with a "normal" wage. But just as the pieceworker could earn somewhat more than a labourer with a fixed day wage, the tip receiver made somewhat more money than the waiter or waitress on a fixed wage, hence the appeal of the tipping system.

The idea that tip receivers were publicans' and restaurateurs' partners, or subcontractors who could organize their business as they saw fit, was an illusion, of course. Serving staff had to comply with working hours and numerous other regulations imposed by their employers, just like any other wage earner.

\section{THE DECLINING ATTRACTIVENESS OF THE TIPPING SYSTEM}

The tipping system not only tended to procure serving staff a higher "wage" than any publican or restaurateur would have paid them, ${ }^{116}$ tips could also apparently be a source of independence and agency. According to the monograph on the waitresses of the Grand Duchy of Baden, they did not wish to be paid a wage because this would entail respecting a period of notice instead of leaving the job when they pleased. Moreover, enticing a customer to give a generous tip also contributed to feelings of excitement: every customer was a challenge. For older waitresses, however, these situations were less appealing and they tended to prefer a fixed wage. ${ }^{\mathrm{II}}$ In any case, while the majority of my historical sources associated tips with feelings of humiliation and servitude, in more contemporary social science studies the idea that it could be more exciting to earn a tip than a wage is sometimes present. Admittedly, many of these

I 4. Encyclopédie socialiste, syndicale et coopérative, pp. 25-26. Historical considerations on the piecework and premium systems can be found in Howard F. Gospel, Markets, Firms, and the Management of Labour in Modern Britain (Cambridge, 1992), pp. 69-74; Daniel Nelson, Managers and Workers: Origins of the New Factory System in the United States, I880-1920 (Madison, WI, 1975), p. 45 .

I 15. "La condition des garçons de café", Le Rappel, 23 April 1907; Evening Telegraph, 7 November 1902.

I16. Kommission für Arbeiterstatistik, Arbeits- und Gebalts-Verbältnisse der Kellner und Kellnerinnen, II, p. 38; H. Grenier, "Le bachich", L'ouvrier syndiqué, I March ı 898; Peter, Zur Lage der Kellnerinnen im Grossherzogtum Baden, p. 36.

I 17. Ibid., pp. 33, 36-37. 
studies are on the United States after the neo-liberal turn, a context that from all points of view is very specific. In her study of waitresses in a New Jersey restaurant in the I980s, Greta Foff Paules, for instance, suggests that the tipping system strengthens the waitresses' conviction that they are capable of influencing the level of their income by their zeal, politeness, and efficiency. ${ }^{118}$ In their study of restaurant servers, Brewster and Wills also found that tipping could be experienced as a source of agency. ${ }^{119}$

But if the tipping system could suit servers' aspirations and autonomy, why was tipping and the practices that went with it subject to increasing criticism from the late i 880 s? Reporting on waiters' agitation in France, the Morning Post stated that Parisian waiters used to earn Fr. 250-300 a month, after deduction of charges, but were left with barely Fr. 60 a month in I 897. ${ }^{120}$ The overcrowding of the labour market in combination with the seasonality involved in much waiting work and the fact that a waiter aged over thirty-five was considered "old" may have contributed to the feeling that in the twenty-odd years of a waiter's career it became increasingly difficult to make a living. ${ }^{2 \mathrm{I}}$

Commenting on French waiters who lived on gratuities, the Coventry Herald remarked in 1886 : "in a short time a waiter becomes a capitalist, and sets up on his own account", but "times are less good than he used to find them". ${ }^{122}$ The enquiry into the situation of waiters in Amsterdam in 1907 noted that the owners or managers of some grand cafés were former waiters, but that starting even a modest café had become difficult: only a minority succeeded. ${ }^{\mathrm{I} 23}$ No longer having the perspective of starting one's own business with money saved from tips may have fuelled waiters' frustrations. ${ }^{\mathrm{I} 4}$ Only waiters, however, were associated with this ambition: while they collected their employers' recommendations zealously, waitresses were portrayed as volatile. ${ }^{\mathrm{I} 5}$ Poetzsch, meanwhile, linked the inability to start one's own business to the fact that the hospitality sector

I 1 8. Greta Foff Paules, Dishing It Out: Power and Resistance Among Waitresses in a New Jersey Restaurant (Philadelphia, PA, I99I), pp. 26-33.

I 19. Zachary W. Brewster and Jeremiah B. Wills, "The Institution of Tipping as a Source of Employee Agency: The Case of Restaurant Servers”, Sociological Focus, 46:3 (2013), pp. 193-2 10, 205. For a historical perspective, also on the US, see Daniel Levinson Wilk, "The Red Cap's Gift: How Tipping Tempers the Rational Power of Money”, Enterprise E Society, I 6 (20 I 5), pp. $5-50$.

I 20. "France", Morning Post, 4 August 1897.

I 2 . Oldenberg, Der Kellnerberuf, p. 38; Hermann Schmidt, Kellners Web und Wobl oder ein Blick in die Kellnerwelt und das Kellnerleben (Basel, I 891), p. 24; De toestand der bedienden in het hotel- en cafébedrijf te Amsterdam, p. 8.

I 22. "The French Waiters", Coventry Herald, I 3 August I 886.

I 23. De toestand der bedienden in het hotel- en cafébedrijf te Amsterdam, p. 8. See also Aan alle geëmployeerden in het logement- en koffiehuishoudersbedrijf, p. 2.

I 24. Oldenberg, Der Kellnerberuf, pp. I 5-I6.

I 25. Peter, Zur Lage der Kellnerinnen im Grossherzogtum Baden, p. 25. 
was more and more becoming a fully capitalist undertaking, with breweries and wine businesses exploiting their own cafés. ${ }^{\mathrm{I} 26}$ Oldenberg, too, evoked the increasing level of concentration in the catering sector. As he argued in I893, the growing impact of big breweries was responsible for this development: a lot of the Bierpaläste (beer palaces) in the big cities were the property of breweries. Salaried Buffetiers were replacing independent landlords. ${ }^{\text {I27 }}$

Reverend Schmidt rather put the blame on the strong increase of very small businesses, resulting in a rising demand for waiters, having a deskilling effect on the serving staff, who increasingly joined the ranks of the Kellnerproletariat. ${ }^{128}$ The Dutch hospitality workers' union, Centralen Bond van geëmployeerden in het logement- en koffiehuishoudersbedrijf, also pointed to the fierce competition between small businesses, which prevented their proprietors from abolishing the tipping system and its abuses. An increasing concentration and the advent of trusts and cartels would solve that problem, providing, of course, that a strong hospitality union defended workers' interests. ${ }^{\text {I29 }}$ While less than ten years earlier this hospitality union had endorsed Eringaard's brochure in which he characterized the waiter as a leaseholder, the acknowledgment of the capitalist development of the catering sector led not only to the Centralen Bond joining the social-democratic federation of trade unions, the Nederlands Verbond van Vakverenigingen, but also to the union's declaration that the waiter had to be paid a wage instead of receiving tips. ${ }^{130}$ Some waiters, however, still hoped they would eventually own their own business: according to the Austrian representative at the socialist unions' international conference, this was one of the reasons why Viennese waiters were so difficult to organize. ${ }^{\mathrm{I} I}$

\section{UNIONS AND TIPPING}

How exactly did serving staff and their organizations react to the tipping system and associated practices? Most of my information pertains to waiters. ${ }^{132}$ Recurrent themes in the mobilization of French waiters' organizations from the late $\mathrm{I} 880$ s until World War I were the abolition of

I26. Hugo Poetzsch, "Trinkgeld und Lohn", Sozialistische Monatshefte, I3:9 (1907), pp. $383-390,390$.

I27. Oldenberg, Der Kellnerberuf, p. 4.

I28. Schmidt, Kellners Web und Wobl, pp. 7-8.

I 29. Nederlandsche Centrale Bond van geëmployeerden in het logement- en koffiehuishoudersbedrijf, Ons standpunt inzake het fooienstelsel (The Hague, I9 I I), pp. I3-I4.

I30. "Het I s-jarig bestaan onzer organisatie", De geëmployeerde, is May i913, I June 1913.

I3 I. Internationale Union der Hotel-, Restaurant- und Café-Angestellten, I. Internationale Konferenz, 1908 , p. I8.

I 32. On the mobilization and demands of hotel and restaurant staff in Italy in the same period, see Paolo Raspadori, "Becoming Workers? Strikes by Hotel and Restaurant Staff in Italy (1902I923)", in this issue, pp. 379-4I I. 
private employment agencies and of the charges reducing tips, as well as the right to wear a moustache. ${ }^{\mathrm{I} 33}$ From the beginning of the $\mathrm{I} 890 \mathrm{~s}$, a daily limit of hours of work, a weekly day of rest, and a (minimum) fixed wage were demanded. Although the tipping system was condemned in principle, there were mixed messages, however, with regard to its abolition. While in I 897 waiters in Marseilles and Paris campaigned against the tipping system, asking the public to deny them their gratuities, ${ }^{\mathrm{I} 34}$ the Congrès national corporatif des employés limonadiers, restaurateurs et assimilés de France held in Marseilles in I90I concluded that abolishing tips was unworkable. ${ }^{135}$ Parisian waiters, striking between 19 April and 3 May I907, demanded one day off per week, the right to wear a moustache, the abolition of charges, and the introduction of a minimum wage. ${ }^{136}$ The pourboire as such, however, was not at stake, not even for the waiters' union of the Confédération générale du travail, although it had officially demanded its abolition at the congress of Bourges in 1904. ${ }^{137}$ A national conference of food workers in Tours in April I9I 3 spoke out against le tronc, charges, and private employment agencies, and demanded a weekly day off and a fixed wage, but the abolition of the tipping system was not demanded; in fact waiters were to be able to keep their tips entirely. ${ }^{138}$

Prior to World War I, the Belgian garçons demanded the abolition of private employment agencies and charges, and, as in Paris, they wanted to be allowed to wear a moustache, ${ }^{\mathrm{I}}{ }^{39}$ but both the Association libre des garçons limonadiers, restaurateurs et hôteliers de la ville de Bruxelles and the socialist Union syndicale kept mostly silent about tips. The Association libre defended the tipping system because it gave the waiter an opportunity to demonstrate his expertise, while it also feared a fixed wage would lead to

I33. In Paris, Brussels, London, and Vienna waiters protested because their employers wanted them to be clean-shaven. See, for example, Alex Tinkel, Der Rasir-Zwang im Stande der GasthofsGehilfen (Vienna, I888).

I34. "Les garçons de café", La Presse, 27 July I897; "Contre le pourboire”, La Lanterne, I 2 August I 897.

I35. L'Ouvrier syndiqué, I November I90I; "Le congrès des limonadiers-restaurateurs", Le Rappel, 24 September $190 \mathrm{I}$.

I 36. "Les garçons de café en grève", Le Figaro, I 8, 19, 20, 22, and 29 April I907; "La grève des garçons-limonadiers", Journal des débats politiques et littéraires, I9 April 1907; "L'agitation ouvrière", La Presse, 23 April 1907.

I37. Fédération nationale des travailleurs de l'alimentation, 3me congrès national des corporations ouvrières de l'alimentation tenu à Bourges, p. 60; E. Protat, "La grève des limonadiers-restaurateurs", L'Alimentation ouvrière, 6 (1907), no. 63.

I38. Le Rappel, 6, 8, and I 3 April I9I3; "Le congrès des garçons de café”, L'Humanité. Journal socialiste quotidien, I 2 April I9I3.

I 39. "Le syndicat de garçons de café", Le Peuple, 5 June i 891; "Les garçons de café”, Le Peuple, 2 I July I 895; "Notre but", Le Combat. Organe officiel de défense des intérêts des garçons limonadiers, restaurateurs, hôteliers, cuisiniers, serveuses, officiers et associations similaires, I:I (1913), p. I. 
price increases, which was bad for business and thus for waiters. ${ }^{140}$ The socialist union was against the tipping system in principle, but argued that as long as authorities had not made the fixed wage compulsory, tips could not be abolished. They were in favour of a fixed wage and considered tips to be a moral obligation on the customer. ${ }^{\mathrm{II}}$

The German social-democratic hospitality workers' union opposed the tipping system, from I 890 onwards, but argued that it was not strong enough to influence conditions in practice. ${ }^{\mathrm{I}{ }^{2}}$ In the Netherlands, according to the Amsterdam report on the situation of waiters, unions did not mobilize against the tipping system. There was allegedly no general dissatisfaction with tipping, although quite a few waiters conceded that it would be much more comfortable to have a fixed wage: it would shorten the workday, because the tipping system led waiters to make extra hours to achieve sufficient income. Some waiters feared, however, that their income might decrease with a fixed wage. ${ }^{\mathrm{I} 3}$ Meanwhile, the Dutch hospitality union agreed in I9I I on the abolition of tipping and the introduction of a fixed wage: between waiter and restaurateur or publican a wage relationship had to be established. ${ }^{44}$

In Britain, Paul Vogel, at the time honorary secretary of the International Waiters', Waitresses', Barmens', Barmaids' and Domestic Servants' Protective Union, in I 894 defended the right to tips of waiters working in the House of Commons, but allegedly only because their wages were too

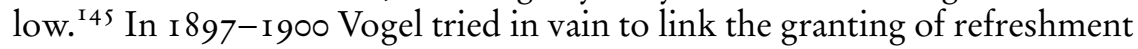
and amusement licences to the payment of a living wage, and he also defended the right to wear a moustache, but a fixed wage did not mean tips had to be abolished: "Lord Kitchener was paid by the State for his services, but when after doing a smart piece of work, he was offered a 'tip' of $£_{25}, 000$, he did not decline it." ${ }^{46}$

I40. Gabriel Bonneaux, "Autour du pourboire”, Bulletin mensuel. Association libre des garçons limonadiers, restaurateurs et hôteliers de la ville de Bruxelles, I:3 (1909), p. 2.

I4I. "Situation des employés des restaurants, cafés et brasseries", Journal de l'Union syndicale du personnel des hôtels, cafés, restaurants et brasseries de Belgique, March 19i4, numéro special; "L'exploitation des garçons de café", Le Peuple, 20 February i 9 I 4.

I42. Poetzsch, Geschichte der Zentralorganisation der Hotel-, Gast- und Kaffeehausangestellten, p. 87; idem, “Trinkgeld und Lohn", p. 390.

143. De toestand der bedienden in het hotel- en cafébedrijf te Amsterdam, pp. 26-27.

I44. Van Heusden, De urgentie van sociale wetgeving, p. 27; Nederlandsche Centrale Bond, Ons standpunt inzake het fooienstelsel, pp. I 5-16; Bond van Hotel-, Café- en Restaurantpersoneel in Nederland, Geen fooi, doch loon! Een woord tot de kelners (Amsterdam, I92 I), p. I.

I45. "Waiters Tips in the House of Commons", Reynold's Newspaper, I April I 894.

I46. "Fair Wages for Waiters”, Edinburgh Evening News, I I September I 897; "Waiters' Tips”, Morning Post, 4 January I 899, "Waiters in Revolt", Daily News, 8 October I 900; "Living on Tips”, The Mercury, 9 November 1900. Lord Kitchener was a British general who was granted a

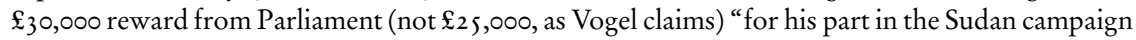
of I 896-98”; Thomas P. Dooley, Irishmen or English Soldiers? (Liverpool, i 995), p. 39. 
Overall, tipping as such was not the main preoccupation of waiters' organizations. At the European socialist hospitality unions' conferences in I 908 and I9I I, tipping did not figure on the agenda, nor was it an important topic in the discussions. Before World War I only the representatives of the Netherlands and Britain explicitly spoke out against it. ${ }^{\text {I47 }}$ Most waiters' unions campaigned for a fixed (minimum) wage in combination with tips. Earning a fixed wage was a precondition for a shortening of the working day. In addition, the embryonic social and labour legislation was largely confined to wage earners. It was also argued that in the slow season or on rainy days the fixed wage guaranteed a more regular income, while the receipt of generous tips should not be prevented when business boomed. Only a minority of waiters' unions defended the demand that tipping be entirely replaced by a fixed wage. In contrast to those of union officials, the opinions of the rank and file have left few traces in the documents available, but as the examples mentioned above indicate, serving staff did not necessarily share waiters' unions' anti-tipping stance. This might explain the reluctance of waiters' unions to do away with tipping altogether.

\section{CONCLUSION}

The exponential growth in the number of restaurants and cafés in Europe's city centres and the increase in travel and tourism in the second half of the nineteenth century provided young men (and to a lesser extent women) who could read, write, and count with many new job opportunities. However, customers' tips increasingly financed these workers' wages and eventually even entirely replaced them.

Echoing the liberal French economist Leroy-Beaulieu (I843-I9I6), the US-American economist Steven Landsburg explains why tip receivers are bound to see their wages decline. ${ }^{\mathrm{I} 8}$ Landsburg's argument is general and not historically specific: as long as the tips represent an extra income, they attract more workers to the hospitality sector, more labour supply leads to lower wages, which "eats up" the extras earned through tips. In the context of the development of the nineteenth century, this downward spiral, one might argue, was set in motion with the rise of literacy; the skills required to be a waiter or waitress were becoming increasingly widespread. The continuous stream of small change bestowed upon front-of-house personnel attracted workers from other sectors, but, these persons' skills being increasingly interchangeable, wages in hospitality declined by an amount similar to that by which tips had risen - until

I47. Union internationale des travailleurs d'hôtel, restaurant et café, 2me Conférence internationale, I9II (Berlin, I9II), pp. $25,52$.

148. Steven Landsburg, Price Theory and Applications (Mason, OH, 2010), pp. 208-209. 
jobs in hospitality were no longer more attractive than occupations requiring similar skills, a moment that saw a sensible turn towards re-establishing a degree of income stability by introducing, or reintroducing, fixed wages. In the long run, so Landsburg concludes, serving staff cannot win. Also, from the customer's point of view, he says, the tipping system seems fraught with contradictions: customers are in fact subsidizing themselves and not the serving staff, because their tips prevent prices from rising.

It would seem, however, that the situation was more complex than Leroy-Beaulieu and Landsburg suggest. The basic skills required for hospitality work may have been evenly spread over a large number of people, but in a sector where vocational schools were slow to develop, workers tried to improve their labour market position by highlighting their style, posture, appearance, and, last but not least, language skills. Hence, the importance of work experience abroad, especially in London and Paris, former employers' recommendations, and photographs accompanying job applications. ${ }^{\text {I9 }}$ Of course, the increasing pressure on everybody working in the sector to improve may have led to a "devaluation" of the skills acquired: "Even the lavatory lady has to know English nowadays", a German waiter exclaimed in 1908. But even then, working in a front-of-house position in the world of hospitality was financially often more rewarding than the alternatives (or at least appeared to be more rewarding): both in the nineteenth century and today serving staff seem to agree that a fixed wage would never be as high as takings from tips. ${ }^{150}$ Apart from the reasons I mentioned earlier, perhaps the decreasing difference between the latter and the level of a "normal wage" was a cause of the declining attractiveness of the tipping system.

That tip receivers' take-home pay seemed to decline was, of course, the result of the efforts of hospitality entrepreneurs to externalize labour costs and other expenses, making not only customers but serving staff themselves contribute. The overcrowding of the labour market was such that hiring workers had not only become a cost-free transaction, it was even a source of income. Serving staff paid for the opportunity to collect tips, even if the increasing number of tip receivers reduced takings, while all sorts of menial and subsidiary tasks were either performed or financed by serving staff, thus enabling proprietors to further economize on the wage bill.

Were serving staff of the pre-war period workers or small entrepreneurs? A comparative analysis of Europe from the end of the nineteenth century

I49. Van den Eeckhout, "Cooks and Waiters on the Move", pp. 308-309.

I 5 O. Emma Dowling, "Producing the Dining Experience: Measure, Subjectivity and the Affective

Worker", Ephemera: Theory E Politics in Organization, 7 (2007), pp. I I7-1 32, I 29. 
until I9I 4 indicates that they were workers who, as a result of the tipping system, often managed to secure higher "wages" than they would normally have earned, but who in their efforts to maintain this situation were increasingly compelled to sacrifice the very perks of the job they were after. A fixed (albeit lower) wage, in combination with the embryonic welfare state's benefits reserved for wage earners, might have become more appealing to a growing group of waiters' associations (though they still represented the minority), but the fact that these discussions appeared to be all but settled in the interwar period is an indication that modelling employment relations in hospitality on the image of the industrial sector was not self-evident.

While the interests and positions of serving staff vis-à-vis standardized labour relations were intricate, extra complexity was added through the involvement of a third party in the employment relationship, the customer. Being characteristic of interactive service work, it lies at the core of the unpredictability of serving staffs' incomes. Customers were perceived either as a threat or as an opportunity: whichever one it turned out to be varied with the economic cycle, the season, the segment of the labour market in which workers operated, workers' ages, and other personal characteristics that were conducive (or not) to yielding tips. It is important to acknowledge that these variations were, on an individual level, real and potent. However, on an aggregate level and seen in the longer run, they nourished the illusion that the income of serving staff could be generally higher than in other sectors. From such a more distant point of view, waiters and waitresses were decidedly workers - exposed to the functioning of the labour market as much as any other worker.

\section{TRANSLATED ABSTRACTS FRENCH - GERMAN - SPANISH}

Patricia Van den Eeckhout. Serveurs, serveuses et leurs pourboires en Europe occidentale avant la Première Guerre mondiale.

Dans les restaurants et cafés du dix-neuvième siècle, les pourboires des clients assuraient le revenu d'un nombre croissant de serveurs et de serveuses. Non seulement les employeurs s'abstenaient de payer un salaire fixe au personnel de service, mais encore ce dernier devait partager les frais généraux de son employeur, certains devant même payer une rétribution pour le privilège de travailler. Examinant les journaux, les pamphlets, les rapports et les sources syndicales, l'article étudie, dans une perspective comparative, comment et pourquoi ces pratiques se sont développées à Amsterdam, Bruxelles, Vienne, Londres et dans des villes françaises et allemandes. En raison du surpeuplement du marché de l'emploi dans l'hôtellerie et la restauration, l'embauche de travailleurs n'est pas seulement devenue une transaction gratuite, elle s'est même développée en une source de revenus. Le personnel de service payait la possibilité de 
pouvoir collecter des pourboires, même si ses effectifs croissants diminuaient le revenu individuel. Mais grâce à ce système de pourboires, ce personnel réussissait souvent à s'assurer des "salaires" supérieurs à ce qu'il aurait normalement gagné.

Traduction: Christine Plard

Patricia Van den Eeckhout. Kellner, Kellnerinnen und ibr Trinkgeld in Westeuropa vor dem Ersten Weltkrieg.

In den Restaurants und Cafés des I9. Jahrhunderts diente das von Kunden gewährte Trinkgeld einer wachsenden Zahl von Kellnern und Kellnerinnen als Einkommen. Die Arbeitgeber gingen nicht nur zunehmend von einem festen Lohn für ihre Bedienungskräfte $a b$, sondern diese mussten sich auch an den allgemeinen Betriebsausgaben beteiligen; manche hatten für das Privileg, arbeiten zu dürfen, sogar eine Gebühr zu entrichten. Der Beitrag zieht Zeitungen, Flugschriften, Berichte und gewerkschaftliche Quellen heran, um auf vergleichende Weise zu erläutern, wie und weshalb diese Praktiken in Amsterdam, Brüssel, Wien und London sowie in französischen und deutschen Städten zum Einsatz kamen. Aufgrund des übersättigten Arbeitsmarktes im Gastgewerbe wurde die Einstellung von Personal nicht nur zu einer kostenfreien Transaktion, sondern sie entwickelte sich sogar zur Einkommensquelle. Bedienungskräfte zahlten für die Gelegenheit, Trinkgeld erhalten zu können, auch wenn ihre steigende Zahl die einzelnen Einkommen sinken ließ. Dennoch konnten Bedienungskräfte durch das Trinkgeldsystem häufig höhere "Löhne" erreichen, als sie normalerweise verdient hätten.

Übersetzung: Max Henninger

Patricia Van den Eeckhout. Camareros, camareras y propinas en Europa occidental antes de la Primera Guerra Mundial.

En los restaurantes y cafés del siglo XIX las propinas de los clientes proporcionaba el sustento fundamental de un número cada vez mayor de camareros y camareras. Los patronos no sólo se abstenían de pagar a este personal de servicio un salario fijo sino que además estos últimos se veían obligados a tener que compartir los gastos generales de sus patronos, e incluso algunos tenían que pagar una tarifa por el privilegio de trabajar. Explorando entre los periódicos, los folletos, los informes y las fuentes sindicales, el artículo plantea desde una perspectiva comparativa cómo y porqué esas prácticas se desarrollaron en Ámsterdam, Bruselas, Viena, Londres y en ciudades francesas y alemanas. Como resultado de la masificación del mercado de trabajo en hostelería y restauración, el alquiler de trabajadores llegó a ser no sólo una transacción a coste cero sino que incluso se desarrolló como una fuente de ingresos. El personal de servicio pagaba por la oportunidad de percibir propinas, incluso si su número cada vez 
mayor reducía los ingresos individuales. Sin embargo, como resultado del sistema de propinas, este personal a menudo maniobraba para asegurarse "salarios" más altos de lo que ellos normalmente habían percibido.

Traducción: Vicent Sanz Rozalén 